\title{
AZ ANOREXIA NERVOSA TÖBB SZEMPONTÚ SZAKIRODALMI ÁTTEKINTÉSE
}

\author{
Szerző: \\ Sáfrány Judit \\ Markhot Ferenc Oktatókórház és Rendelőintézet
}

Szerző e-mail címe: safrany12@gmail.com

\section{Lektorok:}

Mező Ferenc (PhD)

Eszterházy Károly Egyetem

Kelemen Lajos (PhD)

Okoskocka $\mathrm{Kft}$

...és további két anonim lektor

\begin{abstract}
Absztrakt
A különleges bánásmódot igénylő gyermekek, tanulók körében a mai modern kor pszichiátriai zavarai közül az evészavarok egyre nagyobb figyelmet igényelnek. Jelen szakirodalmi áttekintés célja az evészavarokon belül az anorexia nervosa bemutatása. Kitér ezen belül az epidemiológiai, etiológiai adatokra, a diagnosztikai, differenciáldiagnosztikai kritériumokra, illetve figyelembe veszi a komorbiditást. Az evolúciós és rendszerszemléletú megközelítések mellett hangsúlyozza a pszichodinamikus, valamint a kognitív/tanuláselméleti perspektívákat (az OxIPO-modell aspeltusából). Végül a pszichoterápiás hatékonyságvizsgálatok összegzésével az ellátási formák lehetőségére kívánja felhívni a figyelmet.
\end{abstract}

Kulcsszavak: evészavar, anorexia nervosa, OxIPO-modell

Diszciplína: pszichológia, pszichiátria

\section{Abstract \\ DIFFERENT ASPECTS IN THE REVIEW OF ANOREXIA NERVOSA}

As for children and students with special needs for treatment and care considering psychiatric disorders of the modern civilization - such as eating disorders - are taken into consideration. This review is intended to present - within the eating disorders - anorexia nervosa. It includes epidemiological and etiological data, diagnostic and differential diagnostic criteria, comorbidity. Evolutionary and system theory approach, psychodynamic, as well as cognitive/learning theory perspectives are emphasized (from aspect of OxIPOmodel). In the end with the summary of psychotherapy's efficacy investigations, this study aims to highlight the different forms of possible treatment(s).

Keywords: eating disorder, anorexia nervosa, OxIPO-model

Disciplines: psychology, psychiatry

Sáfrány Judit (2019): Az anorexia nervosa több szempontú szakirodalmi áttekintése. OxIPO - interdis₹ciplináris tudományos folyóirat, 2019/1, 33-51. doi: 10.35405/OXIPO.2019.1.33 
A különleges bánásmódot igénylő személyek esetében fokozottan lehet számítani komorbid zavarokra. Amennyiben ezek nem kerülnek felismerésre, vagy kezeletlenül maradnak, tovább fokozhatják a már fennálló problémákat. Korunk egyre nagyobb figyelmet kapó pszichiátriai zavarai az evészavarok, melyek tipikusan gyermek- és serdülőkorban indulnak, azonban felnőttkorra is átívelhetnek. Hazai és külföldi szakemberek egyaránt számos tanulmánnyal járultak hozzá az evészavarok, ezen belül az anorexia nervosa széles körú feltérképezéséhez, melyet jelen szakirodalmi áttekintés bemutat. Szemléletében újdonságnak számít, hogy a különböző pszichológiai iskolák elméleteit integrálja (szervezési elvként az OxIPO-modellt alkalmazva), a több szempontú értelmezést részesíti előnyben. Ennek célja, hogy mind a diagnosztikai, mind a terápiás munkában minél személyre szabottabb lehetőségeket kínáljon.

\section{Epidemiológiai, etiológiai adatok}

Közismert epidemiológiai adat, hogy az evészavarok a modern civilizáció zavarai. Világszerte előforduló pszichiátriai zavarok, melyek prevalenciája 0,3-1\% között mozog, ezen belül az anorexia nervosa $0,9 \%$, a bulimia nervosa $1,5 \%$-os életprevalencia mutatókkal rendelkezik, de az adatok kissé változhatnak attól függően, hogy milyen diagnosztikus kritériumokat veszünk figyelembe a vizsgálatok során (Rikani és mtsai., 2013). A nemek szerinti eloszlást figyelembe véve az anorexia nervosa a nők körében 1\% körül mozog, míg a férfiak aránya 0,5\%-nál is kevesebb (Favaro, Ferrara, és Santonastaso, 2003).

Sokáig élt a „3W” elképzelés, mely alapján a „White Western Women” betegségeinek tartották az evészavarokat (Jánosi és Túry, 2014). Mára már elmondhatjuk, hogy habár valóban az ipari társadalmakban találkozhatunk leggyakrabban a problémával, egyre szélesebb rétegben (mind nem, mind életkor tekintetében) tapasztalható az evészavar prevalenciája. A zavar kialakulásában a korai vagy középső serdülőkor a legjellemzőbb, de bármelyik életszakaszban, akár a gyermekkorban is kialakulhat. Ebben a korai időszakban a nemek szerinti el- oszlás még kiegyenlített (Madden, Morris, és Zurynski, 2009). A felnőttek esetében gyakori, hogy a kezelés csak évekkel a betegség kialakulását követően kezdődik, akár középkorban (Bulik, Marcus, és Zervas, 2012). Ennek ellenére várható tartós gyógyulás a kezelés hatására (40\%), továbbá a serdülőkorban még eredményesebb a terápiás ellátás, amit az ötéves utánkövetés is igazol (Steinhausen, 2002).

A prevenció és a terápiás ellátás sikeressége szempontjából elengedhetetlen, hogy magyarázattal szolgáljanak a vizsgálatok az egyes kórképtípusok esetében. Az etiológiában a bio-pszicho-szociális betegségmodell elsődleges szerepet játszik. Az anorexia nervosa hátterében többek között a szülőktől való függetlenség és önálló életpálya kialakítására irányuló törekvést; affektív zavarokkal, elsősorban a depresszióval való kapcsolatot; a modern kultúra soványságot idealizáló normarendszerét, illetve a tradicionális értékekkel szembeforduló modern nők önértékelésének igényét feltételezik (Condit, 1990).

A bio-pszicho-szociális modell keretében beszélhetünk hajlamosító (prediszponáló), kiváltó (precipitáló) és betegségfenntartó tényezőkről (Túry és Szabó, 2000). Az önértékelési zavarok, a kényszeres vagy depresszív személyiség, illetve a perfekcionizmus mint hajlamosító tényezők azonosíthatóak. Szintén rizikófaktornak tekinthetők a családi körülmények, úgymint a családi anamnézisben fellelhetô evészavarok, hangulatzavarok, addikciók, illetve a gyermek diétára történő ösztönzése. A kiváltó tényezők között különböző stresszorok, negatív életesemények, a testsúllyal vagy az alakkal való elégedetlenség és az ebből következő diétázás szerepelhetnek. Nem ritka, hogy az evészavarral küzdő beteg tünetei egyensúlyfenntartó funkciót töltenek be a családi vagy más rendszerekben, amire főként a terápiarezisztens helyzetekben kell gondolnunk.

$\mathrm{Az}$ anorexia nervosa kezdetben bizonytalan besorolású volt a hazai szakirodalomban, elsősorban belgyógyászati tankönyvekben kapott helyett. Az 1980-as évek hozta meg a változást, amikor pszichoszomatikus megközelítése tért nyert, és már nemcsak endokrinológiai kórképnek tekintették (Túry és Pászthy, 2008). 
Mai ismereteink szerint már tudjuk, hogy a gyermek- és serdülókorban induló anorexia nervosa súlyos, életveszélyes pszichiátriai betegség, ami a felnőttkorra átívelhet. A legveszélyeztetettebb korosztály a 14-16 éves kor közötti serdülők, azonban egyre inkább prepubertás korban is fellelhetőek megbetegedések (Pászthy, 2007). A serdülő lányok körében a harmadik leggyakoribb krónikus megbetegedés az anorexia (0,3-0,8\%), az atípusos és szubklinikai eseteket is figyelembe véve 1-3\%-ról is beszélhetünk (Fisher, 2006). A fiúk körében a korai kezdet valószínúbb (Peebles, Wilson, és Lock, 2006), de elsősorban a nôket érintő megbetegedésrôl van szó.

A statisztikai adatok szerint a legnagyobb mortalitású pszichiátriai kórkép, felnőtt személyeknél a betegségindulást követő tíz évben 10\%, húsz éven belül 20\% körüli a halálozási arány (Túry és Szabó, 2000). A serdüló korosztályban végzett longitudinális vizsgálat 5\%-os mortalitási rátát jelzett (Steinhausen, 2002). A halálok elsősorban szervi szövődmény, valamint kisebb százalékban szuicidium (Fisher, 2006). A betegséget túlélő betegek körében $47 \%$ az, aki gyógyultnak tekinthető, $33 \%$ némely tünetében javulást mutat, 20\%-nál pedig az anorexia nervosa krónikussá válik (Steinhausen, 2002).

Mind a vulnerabilitás, az etiológia, mind a fenntartó tényezôk tekintetében a bio-pszicho-szociális szemlélet a legrelevánsabb (Túry, Lukács, Rácz, és Horváth, 2003). Az anorexia nervosa kockázati tényezői között a szülók pszichopatológiája, magasabb iskolai végzettsége, az anya overprotektív ma- gatartása, a családban előforduló anorexia, korai etetési problémák, gyermekkori szexuális abúzus, alacsony önértékelés, valamint a jelentős emocionális labilitás első helyen szerepel (Friedman, 1997).

\section{Diagnosztika}

Az 1. és a 2. táblázatok foglalják össze az anorexia nervosa BNO-10 (2004), illetve DSM-5 (2014) szerinti kritériumait.

A gyermekkori evészavarok diagnosztikájához a londoni Great Ormond Street Kórház szakemberei a gyermekkori fejlődés sajátosságait figyelembe véve kritériumokat fogalmaztak meg (Great Ormond Street Criteria: GOS) (Nicholls, Chater, és Lask, 2000; Lask és Bryant-Waugh, 2007). A GOSkritériumok a következők: határozott súlycsökkenés; testképzavar; valamint a testsúlyra, a testalakra, illetve a táplálkozásra való túlzásba vitt fókuszálás.

A GOS-kritériumok mellett néhány kritikus tünet figyelembevétele elengedhetetlen a pontos diagnózis felállításhoz.

A megváltozott táplálkozási magatartás a környezet számára is könnyen felismerhető, a kalóriabevitel korlátozására irányul. Jellegzetes tünet, hogy az anorexiás gyermek elutasítja a közös evéseket a szülőkkel, az étel kiválasztásánál nagy gondot fordít a kalóriaszegény ételfajtákra, kalóriát számol, sajátos, az étkezésre kialakított rituálékat alkalmaz, lassan fogyasztja el a kisebb darabokra osztott ételt, illetve evés előtt túlzott folyadékbevitel figyelhető meg, az el nem fogyasztott ételt elrejti, felhalmozza, a családnak rendszeresen főz, míg ô maga csak kalóriaszegény ételeket eszik.

1. táblázat: Az anorexia nervosa diagnosztikai kritériumai a BNO-10 alapján (BNO-10, 2004)

\begin{tabular}{|c|l|}
\hline \multicolumn{2}{|c|}{ Anorexia nervosa $\quad$ F50.0 } \\
\hline A & $\begin{array}{l}\text { A kornak, testmagasságnak megfelelő minimális testsúly fenntartásának visszautasítása (pl. a súlyvesztés } \\
\text { odáig fajul, hogy a test súlya az elvárható testtömeg } 85 \% \text {-nál kisebb lesz, vagy a növekedés során a súlygya- } \\
\text { rapodás nem kelló mértékú, így a test súlya az elvárható testtömeg } 85 \% \text {-nál kisebb lesz). }\end{array}$ \\
\hline B & A soványság ellenére intenzív félelem a súlygyarapodástól vagy elhízástól. \\
\hline C & $\begin{array}{l}\text { A saját test súlyának vagy alakjának észlelése zavart szenved, a test súlyának vagy alakjának túlzott befolyása } \\
\text { van az önértékelésre vagy az alacsony aktuális testsúly súlyosságának tagadása. }\end{array}$ \\
\hline D & $\begin{array}{l}\text { Ivarérett nőkben amenorrhea, azaz legalább három, egymást követő menstruációs ciklus kimaradása. (Ab- } \\
\text { ban az esetben beszélünk amenorrhearól, ha a ciklus csak hormonkezelés, pl. ösztrogén következtében je- } \\
\text { lentkezik.) }\end{array}$ \\
\hline
\end{tabular}


2. táblázat: Az anorexia nervosa diagnosztikai kritériumai a DSM-5 alapján (DSM-5, 2014)

\begin{tabular}{|c|l|}
\hline \multicolumn{2}{|c|}{ Anorexia nervosa $\quad$ F50.0 } \\
\hline A & $\begin{array}{l}\text { Az energiabevitel a szükséges energiamennyiséghez viszonyított korlátozása, mely az életkor, nem, fejlődés és } \\
\text { testi egészség szempontjából jelentôsen alacsony testsúlyt eredményez. A jelentôsen alacsony súly definíció } \\
\text { szerint olyan testsúly, ami alacsonyabb annál, mint ami minimálisan normális, vagy gyermekek és kamaszok } \\
\text { esetében kevesebb, mint ami minimálisan elvárható. }\end{array}$ \\
\hline B & $\begin{array}{l}\text { Intenzív félelem a testsúlygyarapodástól vagy az elhízástól, vagy a testsúlygyarapodást akadályozó tartósan } \\
\text { fennálló viselkedés a jelentősen alacsony testsúly ellenére. }\end{array}$ \\
\hline C & $\begin{array}{l}\text { A testsúly vagy a testalak megélésének zavara, a testsúly vagy testalak önértékelésre gyakorolt indokolatlan és } \\
\text { aránytalan befolyása vagy a jelen alacsony testsúly súlyosságával kapcsolatos felismerés tartós hiánya. }\end{array}$ \\
\hline
\end{tabular}

A szomatikus tünetek között állandó teltségérzetet él át, hasfájása van, nem tudja lenyelni az ételt. A szövődmények a táplálkozási rehabilitációval nagyrészt helyreállnak, azonban néhány következmény irreverzibilis. A leggyakoribb panaszok a következők: „fáradékonyság, szédülés, kollaptiform rosszullétek, evés utáni teltségérzet retroszternális fájdalom, hasi fájdalom, obstipáció, iskolai teljesítményromlás, jelentős hangulatingadozások" (Túry és Pászthy, 2008, 29. o.). Súlyos szövődményeket okozhatnak a só-víz háztartás eltérései. Hipernatrémiás exsiccatio léphet fel a folyadékbevitel szándékos korlátozása miatt, valamint a víz- és hashajtókkal történő abúzus, a gyakori hányás miatt exsiccosis és /vagy hypokalaemia feltételezhető. A tartós éhezés állapotához hypophosphataemia társulhat. Az orvosi felügyelet során rendkívül fontos a rendszeres laboratóriumi ellenőrzés, különös tekintettel a só-víz háztartási állapot figyelemmel követése. Az úgynevezett újratáplálási szindróma azt jelenti, hogy a tartós éhezést követő táplálás ideiglenes, azonban életveszélyes só-víz háztartási kilengéseket okozhat. Szívelégtelenség, izomgyengeség, immundiszfunkció, de akár halál is lehet a következmény. Az újratáplálást tehát a fokozatosság elve szerint szükséges elkezdeni, a kívánt testsúlygyarapodás $0,1 \mathrm{~kg} / \mathrm{nap}$. Hosszú távú szövődmény továbbá az osteopenia (a csontok ásványianyagsűrűségének tartósan alacsony szintje), valamint a hossznövekedésbeli elmaradás (Túry és Pászthy, 2008).

Viselkedéses tünet, hogy az érintett naponta többször mérlegre áll, testsúlyát ellenőrzi; intenzív testedzést folytat, állandóan mozgásban van. Gyakran él át bűntudatot, ha nem tud elegendő testmozgást végezni, illetve ha saját szubjektív mércéjéhez viszonyítva többet eszik. Utóbbi esetben önhánytatás vagy hashajtókkal való visszaélés előfordulhat.

Pszeudoérettség jellemzi óket, korosztályukhoz viszonyítva a felelősségvállalás és a megbízhatóság szempontjából előrébb tartanak, kontrolligényük magas, társas helyzetekben fokozottan ügyelnek arra, hogy a normáknak megfelelóen viselkedjenek (Lask és Bryant-Waugh, 2007).

\section{Komorbiditás, differenciáldiagnosztika}

A betegség progresszív jellegú, idővel egyéb pszichés tünetekkel egészül ki a tüneti kép, úgymint az ingerlékenység, a depresszió, a szociális visszahúzódás, a kortárskapcsolatok problémássá válása, az ételre és az evésre való beszúkültség, valamint a kognitív teljesítmény romlása (Lask és BryantWaugh, 2007). Konkrét társuló betegségek is felfedezhetőek: a depresszió 53,5\%-ban, a disztímia $42,5 \%$-ban, a szociális fóbia $25,5 \%$-ban a generalizált szorongás $27,2 \%$-ban, a kényszerbetegség pedig 8,5\%-ban szerepel másodlagos diagnózisként (Kaye, Bulik, és Thornton, 2004; Hudson, Hiripi, és Pope, 2007).

A fiatalabb korosztály esetében is már számolnunk kell az evészavarhoz társuló pszichiátriai diagnózisokkal. Ebben az esetben azonban hosszabb terápiás ellátásra és szerényebb terápiás eredményekre számíthatunk. A már bemutatott pszichiátriai kórképek mellett a szerhasználat szintén 
komorbiditást mutat az evészavarokkal, elsősorban felnőttkorban. Gyakran amfetaminokkal, koffeinnel, dohánnyal való visszaélés jellemző, aminek célja az étvágy és a testsúly kontrollálása. Az alkohol abúzus inkább a bulimia nervosában szenvedő serdülők esetében okoz problémát. A hashajtókkal, vízhajtókkal, fogyasztó tablettákkal és hánytatószerekkel való visszaélés specifikusan jellemzó az evészavarokban. Ezenkívül a stimulánsok valamint a thyroxin nem rendelvény szerinti használata szintén előfordul. A legtöbb esetben az anamnézisfelvétel során nem kerülnek feltárásra ezek a problémák, és a szülőktól nyert heteroanamnesztikus információk segíthetik a munkát (Eating Disorders Toolkit, 2008).

A differenciáldiagnózis fontos feladata, hogy azonosításra kerüljenek azok a serdülók, akikre jellemző a súlyvesztés, azonban nem evészavar áll a háttérben. Ebben az esetben a súlycsökkenés nem feltétlenül nem-szándékos, jellemző lehet a testképzavar hiánya, valamint az általános paraméterekhez szükséges súlygyarapodás igénye társulhat. Orvosi okai szintén lehetnek a fogyásnak, úgymint gasztrointesztinális betegségek vagy agytumor, illetve a mentális egészség is érintett lehet (depresszió, pszichózis, szkizofrénia) (Eating Disorders Toolkit, 2008).

\section{Magyarázó elvek, megközelítések}

Az anorexia nervosa kialakulását magyarázó szerteágazó elméletek, megközelítések rendszerezésére az alábbiakban az OxIPO-modellt (korábbi szakirodalmakban: IPOO-modellt, lásd: Mező, 2011, illetve Mező és Mező, 2005) alkalmazzuk (1. ábra).

$\mathrm{Az}$ anorexia nervosa kialakulását magyarázó megközelítések közül a kognitív/tanuláselméleti jellegúek ugyanis egyértelműen magyarázhatók a tanulást (beleértve a maladaptív viselkedésminták tanulását is) információfeldolgozó folyamatnak tekintő OxIPO-modell aspektusából. Az evolúciós elméletbeli megközelítés és a rendszerszemléletú tényezők legközvetlenebb módon a körülmények (például: család, környezet stb.) spontán szervező- dése felól kapcsolódnak az OxIPO-modell organizáció komponenséhez; míg a pszichodinamikus magyarázatok a process komponenshez (az anorexiás tünetek hátterében álló emocionális/kognitív információfeldolgozáshoz, maladaptív megküzdési stratégiához) köthetők.

\section{Evolúciós pszichológiai elméletek}

A pszichopatológiák különböző formáinak egyre gyakoribbá válása magyarázható azzal, hogy a nyugati társadalmakban mind nagyobb hangsúlyt kap a sikeressé válás szükséglete, ami a versengő stratégiák térhódításához vezet. Az anorexia nervosa egyik alapvetô meghatározója a karcsúságra törekvés. A karcsúság iránti vágy egyre inkább elterjed, mint a társadalomban való biztos pozíció elnyeréséért való küzdelem eszköze (Ferreira, Gouveia, és Duarte, 2013). Egyértelműnek tűnhet csupán a karcsúságra törekvést, ezáltal a nők közötti szexuális versengés magyarázatát elfogadni, mint a kórkép evolúciós szemléletű hátterét. Ennél azonban szélesebb az evolúció elméletrepertoárja.

A „reproduktív szupresszió hipotézis” egy lehetséges alternatívaként szolgál az anorexia nervosa viselkedéses jegyeinek kialakulásában, fiatal nők körében. Az elmélet szerint az ôsi időkben a nőknek szembe kellett nézniük olyan környezeti feltételekkel, amikhez a reproduktív törekvéseket igazítani kellett (Salmon, Crawford, és Walters, 2008). A nők tehát képesek arra, hogy nem megfelelő körülmények között szaporodási képességüket csökkentsék, ezáltal a megtermékenyülést egy alkalmasabb időpontra halasszák (Wasser és Barash, 1983).

A modern nők szenzitívek a fizikai erőforrások elérhetôségével kapcsolatban - úgymint a táplálék, illetve a környezet emocionális támogatása (Roberts és Miner, 2010). Azok a nők, akik viszonylag kismértékủ társas támogatásban részesülnek, főként a szerelmi partnertôl és a családtól, jellemzőbben említenek diétázási szokásokat, és ritkábban számolnak be arról, hogy készen állnak a szülői szerepre (Juda, Campbell, és Crawford, 2004).

Az akceleráció, azaz a későn és korán érők szempontjából is magyarázattal él az elmélet egy 
másik értelmezése (Surbey, 1987). A modern társadalmakban a korán és későn érő személyek eltérô élettörténettel rendelkeznek. A korán érő lá- nyok a szexuális élettel korábban ismerkednek meg, ezáltal megnő az esélye a nem kívánt terhességnek is.

1. ábra: Anorexia nervosa az OxIPO-modell aspektusából (forrás: Mezọ, 2011 alapján a Szerzố)

\begin{tabular}{|c|c|c|c|c|}
\hline „TELJESITMÉNY” = & ORGANIZÁCIÓ & INPUT & PROCESS & $x \quad$ OUTPUT \\
\hline $\begin{array}{c}\text { Anorexia } \\
\text { nervosa }\end{array}$ & $\begin{array}{l}\text { Azok a sajátos (spontán) } \\
\text { történések és körülmények } \\
\text { (például: család, divat, énkép } \\
\text { stb.), amelyek biztositják az } \\
\text { anorexia megjelenéséhez } \\
\text { szükséges inputokat, informá- } \\
\text { ciófeldolgozási folyamatokat, } \\
\text { tüneteket. }\end{array}$ & $\begin{array}{l}\text { Az anorexia } \\
\text { hátterében álló } \\
\text { ingerkörnyezet. }\end{array}$ & $\begin{array}{l}\text { Az ingerek anorexiá- } \\
\text { hoz vezető kogni- } \\
\text { tív/emocionális fel- } \\
\text { dolgozása. }\end{array}$ & $\begin{array}{l}\text { Az anorexia (szo- } \\
\text { matikus, viselke- } \\
\text { déses, kognitiv) } \\
\text { tünetegyüttese }\end{array}$ \\
\hline \multicolumn{5}{|c|}{ Példák az anorexia nervosával kapcsolatos magyarázatok, megközelítések OxIPO-modell szerinti értelmezésére:** } \\
\hline $\begin{array}{l}\text { Evolúciós megközelités. } \\
\text { Példa Juda, Campbell, és } \\
\text { Crawford (2004) alapján: }\end{array}$ & $\begin{array}{l}\text { Társas környezet, mely a beteg } \\
\text { szempontjából kevés társas } \\
\text { támogatást nyújt. }\end{array}$ & $\begin{array}{l}\text { Kis mértékú társas } \\
\text { támogatás érzése. }\end{array}$ & $\begin{array}{l}\text { Maladaptív alkal- } \\
\text { mazkodást szolgáló } \\
\text { információfeldolgo- } \\
\text { zás: a reprodukciós } \\
\text { esélyek csökkentése }\end{array}$ & $\begin{array}{l}\text { Diétázási szoká- } \\
\text { sok jellemzöbbek, } \\
\text { szülöi szerepre } \\
\text { való készenlét } \\
\text { érzése kisebb. }\end{array}$ \\
\hline $\begin{array}{l}\text { Rendszerszemléletü megköz- } \\
\text { elítés. Példa Karwautz és } \\
\text { mtsai. (2002) alapján: }\end{array}$ & $\begin{array}{l}\text { Család abnormális kapcsolati } \\
\text { mintákkal. }\end{array}$ & $\begin{array}{l}\text { Családtól származó } \\
\text { sajátos ingerkon- } \\
\text { stelláció }\end{array}$ & $\begin{array}{l}\text { Pszichoszomatikus } \\
\text { tünetképződés }\end{array}$ & Anorexiás tünetek \\
\hline $\begin{array}{l}\text { Pszichodinamikus megköze- } \\
\text { lités. Példa Gáti, Túry, és } \\
\text { Wildmann (2001) alapján: }\end{array}$ & $\begin{array}{l}\text { Abúzushoz vezető szociális } \\
\text { környezet. }\end{array}$ & Abúzus élménye & $\begin{array}{l}\text { Elháritó mechanizmus } \\
\text { célja: saját test } \\
\text { aszexuálissá tétele }\end{array}$ & $\begin{array}{l}\text { Tünet: a trauma } \\
\text { szimbolikusmeg- } \\
\text { jelenése }\end{array}$ \\
\hline $\begin{array}{l}\text { Kognitív/tanuláselméleti } \\
\text { megközelítés. Példa } \\
\text { Williamson, Davis, } \\
\text { Duchmann, McKenzie, és } \\
\text { Watkins (1990) alapján: }\end{array}$ & $\begin{array}{l}\text { Karcsúságot ideálnak tekintő } \\
\text { társadalom. }\end{array}$ & $\begin{array}{l}\text { Alakra és súlyra } \\
\text { vonatkozó } \\
\text { diszfunkcionális } \\
\text { élmények, gondolatok, } \\
\text { melyek szorongást } \\
\text { keltenek. }\end{array}$ & Szorongás redukciója & $\begin{array}{l}\text { Fanatikus } \\
\text { kísérletek a } \\
\text { testsúly } \\
\text { csökkentésére }\end{array}$ \\
\hline
\end{tabular}

*Ebben az esetben a „teljesítmény” a személy által nyújtott szomatikus, kognitív, emocionális és viselkedéses jellemzők olyan összessége, ami „Anorexia nervosa” diagnosztikai kritériumainak felelnek meg.

**Tekintve, hogy egy-egy megközelítésen belül többféle értelmezés is létezik, az itt felsorolt Szerzők, mint jellegzetes, de nem kizárólagos képviselői az adott megközelítéseknek.

Az anorexiás nó teste kevesebb férfi számára vonzó, csökkenti a nő libidószintjét, ami lehetővé teszi számára, hogy elég időt nyerjen felsőfokú tanulmányai elvégzéséhez, és a karrierépítéshez, ami családjában magas értéknek számít. Az anorexiából felépülve a nő nagyobb eséllyel indul egy rep- roduktív szempontból értékesebb partner megszerzésében.

$\mathrm{Az}$ anorexia nervosa tehát jellemzően a korán érő, nőiesebb lányoknál alakul ki, akiknél akár a szexuális abúzus veszélye is nagyobb. A másodlagos amenorrhea és a szexualitás késleltetése, ebből 
következően a szaporodás gátlása ösztönös stratégiaként értelmezhetó, amely a természetes szelekció folyamatának eredménye.

Guisinger (2003) kritikája az elmélettel szemben többek között, hogy nem magyarázza a testképzavart és a hiperaktivitást az anorexia tünetei között, illetve nem ad választ arra a kérdésre, miért fordul elô ilyen jellegú megbetegedés férfiak és menopausa után lévő nők esetében.

\section{Rendszerszemléletü megkö̈zelités}

$\mathrm{Az}$ anorexia nervosa paradigmatikus értékủ pszichoszomatikus zavar, hiszen nyomon követhetőek benne társadalmi-kulturális (úgymint a karcsúságideál nyomása), pszichológiai (egyéni és családdinamikai) faktorok és biológiai eltérések (Túry és mtsai., 2003).

Az evészavarok etiológiájának valamint fenntartó tényezőinek megismerésében a rendszerszemlélet, a családi diszfunkciók feltárása kiemelkedő szerepet játszik. Általánosságban elmondható, hogy a szülők overprotektív magatartása, a gyermekek autonómiájának akadályoztatása, a kommunikációs nehézségek, a konfliktuskerülő magatartás, az érzelmek kifejezésének nehézsége jellemző (Sztanó, Ress, és Pászthy, 2007). Gyakran a tünetek szerepe, hogy eltereljék a figyelmet más problematikus területekről (Túry és Szabó, 2000). A 19. században Laségue az evészavarban szenvedő gyermek és családja között patológiás kapcsolatot vélt felfedezni, ezért a parentectomiában, vagyis a családtól való kiszakításban, a kórházi körülmények között való elhelyezésben látta a megoldást. Az 1950-es években már a szülők pszichopatológiájának szerepét ismerték fel, majd az 1970-es években a családi rendszer, a szülő-szülő, valamint szülő-gyermek kapcsolat előtérbe került, amivel az interperszonális szemlélet kezdett tért nyerni (Túry, Simon, Wildmann, és Kiss, 1994).

A rendszerszemlélet értelmezésében az egész több mint a részek összege, és valamely rész megváltoztatása változást idéz elő az egészben is. A család mint homeosztatikus nyilt rendszer, melyben az indexpáciens betegsége a családi egyensúly feltétele. Nem ok-okozati összefüggésekkel próbál tehát a megoldáshoz eljutni, hanem a családi rendszeren belüli folyamatokra kérdez rá, melyek etiológiai és fenntartó tényezókként értelmezhetőek (Vandereycken, Kog, és Vanderlinden, 1989; Epstein és Bishop, 1987).

Azokban a családokban, ahol pszichoszomatikus zavar fordul elő, Minuchin (1974) tipikus diszfunkcionális tranzakcionális és szerveződési mintákat azonosított. Ezek között szerepel az összemosottság, a túlvédés, a rigiditás, a konfliktusok megoldásának nehezítettsége, a gyermek családi konfliktusokba való bevonása. Az összeolvadás az extrém mértékű közelséget jelzi, a családtagok hajlamosak egymás gondolataiba, emócióiba, viselkedésébe, illetve kommunikációjába bevonódni. Az egymás közötti határok elmosottak, a családi szerepek és feladatok összefolynak. A túloltalmazás az egymás iránti fokozott gondoskodást, érdeklődést fejezi ki, a szülők gyermekeiket mindentôl óvják. A merevség a változással szembeni ellenállást, a kialakult szabályokhoz való túlzott ragaszkodást jelenti. Törekszenek rá, hogy egységes és harmonikus család látszatát keltsék, és minden baj egyetlen forrásaként a betegséget jelöljék meg. A konfliktuskerülés az alacsony frusztrációs küszöböt, a konfliktusok megoldásának hiányát jelzi. Végül jellemző a beteg gyermek indokolatlan bevonása a familiáris konfliktusokba. Okon és munkatársai (Okon, Greene, és Smith, 2003) vizsgálatukban megállapították, hogy egy családi veszekedés képes aktiválni az evészavaros tüneteket.

Selvini-Palazzoli és munkatársai (SelviniPalazzoli, Boscolo, Cecchin, és Prata, 1974) is felfedezett az „összemosott” családokban jellemző interakciós mintákat: a kommunikációban a családtagok elutasítják vagy érvénytelenítik a másoktól érkező üzeneteket (mind tartalmi, mind kapcsolati szinten); a vezetô szerepek vállalása elől kitérnek; gyakoriak a titkos koalíciók a családtagok között, de megakadályozzák két tag nyilt szövetségét egy harmadik személlyel szemben; illetve a hibák felvállalása egyik családtag részéről sem valósul meg (Onnis, 1993).

A családok és az anorexia nervosa összefüggéseit vizsgáló tanulmányok számos törvényszerűséget 
állapítottak meg. Casper és Troiani (2001) eredményei alapján a restriktív és bulimiás altípus közül utóbbiak kórosabbnak ítélték meg a családi múködést, ami arra enged következtetni, hogy az anorexiás családokban jellemző egyfajta problématagadó magatartás. Bailey szerint (1991) a bulimia nervosaszerú tünetek előtérbe kerülésével párhuzamosan csökkent mértékű kohézió, gyengébb kifejező készség, több családi konfliktus észlelhetó, valamint nagyobb hangsúlyt helyeznek a teljesítményre.

A családon belüli autonómia tekintetében az evészavarban szenvedő lányok úgy érzik, kevesebb autonómiát kapnak szüleiktől, viszont lánytestvéreikhez viszonyítva azonos érzelmi kötődésről számolnak be szüleik irányában (Karwautz és mtsai., 2003). A szüleikkel való kapcsolatot, fóként az apához füződő viszonyt egységesen elégedetlenséggel minősítették, valamint a testvéri kapcsolatokat is problémásnak ítélték (Jozefik, Iniewicz, Namyslowska, és Ulsaniska, 2002). Ezekben a családokban gyakori a bizonytalan kötődés, a kapcsolati minták abnormálisak (Karwautz és mtsai., 2002). Az anyák részéról jellemző a féltékenység, a versengés, a lányuk étkezési szokásaival, testsúlyával, valamint testalakjával szembeni aggodalom (Rorty, Yager, Rossotto, és Buckwalter, 2000). A gyermek evési attitűdjét meghatározza a szülő ideális testsúly iránti elvárása. Az evészavar transzgenerációs hatást mutat, az anyák evészavara prediktív faktor (Keel, Heatherton, Harnden, és Hornig, 1997). A gyermekkori táplálkozási problémák már az anya saját problémájának következményei (Whelan és Cooper, 2000). A közvetítő faktorok két hipotézis mentén értelmezhetőek: egyrészt az anya modellként szolgál lánya számára, másrészt a közöttük lévő kapcsolat játszhat meghatározó szerepet (Ogden és Steward, 2000). További családi kockázati tényező a túlzott mértékű szülői aggódás. $\mathrm{Az}$ anorexiás gyermekek édesanyja több esetben a terhessége alatt jobban félt a magzat elvesztésétól; fokozottabb distresszt élt át később is, például az óvodába szoktatás idején; a gyermek alvása nem volt problémamentes, illetve későbbi időpontban volt először távol szüleitôl egy egész hétvégére (Shoebridge és Gowers, 2000).
A család lakóhelyét illetően szimbolikusan szintén tükröződnek a rendszer múködésének jellegzetességei. Az ajtók és válaszfalak hiánya jelzi, hogy a családtagok magánélete sem különül el. Az étkezési szokások nagy hangsúlyt kapnak a napirendben, az étel elkészítése mintegy rituálészerúen zajlik (Dévald, 1993).

Jeammet és munkatársai (Jeammet, Gorge, Zweifel, és Flavigny, 1973) az evészavaros páciensek vizsgálatába bevonták a családtagokat is, és az apák vizsgálata alapján hat csoportot különböztettek meg: 1. a család életében nem jelen lévő apák (válás vagy halál); 2 . személytelen apák, akik gyakorlatilag kimaradnak a családi életből, mégis jelen vannak; 3. ellen-ödipális szerepben lévő apák (erotizált apa-lánya kapcsolat); 4. anyáskodó, az ödipális problémák miatt anyai pozíciót betöltó apák; 5. perszonopátiás apák (többek között alkoholizmus); 6. pszichotikus állapotban lévő apák.

A nemzetek közötti összehasonlító vizsgálatok értelmében az autonómia, a diszfunkcionális családon belüli kohézió, valamint az összemosódás kultúrától függetlenül jellemző az evészavaros családok múködésére (Sztanó, Ress és Pászthy, 2007).

A szülők kapcsolata kiemelt figyelmet érdemel az evészavarosok családjában. A pár tagjai nehezen verbalizálnak, ha saját kapcsolatuk meghatározása szóba kerül, és jellemzően bevonnak egy harmadik személyt az interakcióba, aki általában gyermekük. Amennyiben ez állandósul, az ebből adódó emocionális stressz pszichoszomatikus tünetképzéshez vezet, és a gyermek megbetegedéséhez vezet. Ezáltal lehetővé válik, hogy a párkapcsolati konfliktusok rejtett feszültségei helyett gyermekük anorexiája miatt aggódjanak. Mivel igyekeznek az ideális család mítoszát fenntartani, a valódi érzelmek kifejezése, verbalizálása meggátolt, a család szétesésének elkerülése miatt egyfajta ,alexitímiás” múködésmód nyer megerősítést (Onnis, 1993).

A rendszerszemlélet alapján összességében elmondható az anorexia nervosában szenvedő személyek családjáról, hogy a külvilágtól elszigetelten élnek, anakronisztikus vonásokkal teli családideáljuk van, az agresszió és a szexualitás tabuként kezelt terület, a két szülő kapcsolata hierarchizált, va- 
lamelyikük alárendelődik, erősen teljesítményorientáltak, az orális területek - úgymint az étkezés hangsúlyozottak, a diszfunkcionális párkapcsolat ellenére a szülók a harmónia látszatára törekszenek, valamint a megbetegedés általában a legkevésbé problémás gyermeknél alakul ki (Becker, 1980).

A szülői manipulációs modell értelmében a szülôk specifikus befolyással vannak az anorexia kialakulása vagy fennmaradása szempontjából. Az elmélet komoly, a felszín alatt zajló szüló-gyermek küzdelmet feltételez, amelynek hátterében az ellentétes reproduktív érdekek állnak.

A domináns és túlvédő anyák hatékonyan képesek megakadályozni lányuk pártalálását, így reprodukcióját, ami együtt jár azzal, hogy késleltetik/ megakadályozzák az anyáról való leválást (Steiger, Bruce, és Israel, 2003).

Az anorexia előnyös a szülői fitnesz szempontjából. A lánygyermekek anorexiás, vagy más, a reprodukció elfojtásában szerepet játszó megbetegedése - főként a felsô-közép és felsőbb osztálybeli családokban - eszközként szolgálhat arra, hogy a nagyobb reprodukciós potenciállal rendelkező gyermekeikre (azaz fiúgyermekeikre) fordítsák erőforrásaikat.

Az anorexia a páciensek fitneszét azonban csökkenti, hiszen az elfojtott reprodukció biológiailag diszfunkcionális, az anorexiás személy reproduktív értékét csökkenti. A szülők tulajdonképpen egy bonyolult mechanizmuson keresztül megelőzik a gyermek természetes drive-jának (reprodukció) kifejlődését. A szülők indítéka én-központú és genetikailag megalapozottan önző viselkedés (Voland és Voland, 1989).

\section{Pszichodinamikus megközelités}

Az anorexia nervosáról való gondolkodást a pszicho-dinamikus szemlélet jól értelmezhetővé teszi. A betegség kialakulásában a személyiségfejlődés, az evészavar kapcsolati üzenete és szimbolikája, a szociális közegben játszott közelség-távolság kontrolláló szerepe kulcskérdés.
Freud a 19. század végén az étvágy és a libidó csökkenését egymással összefüggésben lévő jelenségként értelmezte. A 20.század elején továbbra is foglalkoztatta az evészavarok, ezen belül is az anorexia nervosa háttere, és felfedezte, hogy a serdülőkorban előtérbe kerülő nemiséggel szembeni ellenérzés, hárítás, regresszív reakció fellépése a betegség (Dévald, 1993).

A korai pszichoanalitikusok a traumatikus eredetú ösztönfixáció, valamint az intra-pszichés konfliktusok etiológiai szerepére helyezték a hangsúlyt (Lane, 2002). Úgy gondolták, a pszichoszexuális fejlődésben az ödipális időszak, a háromszemélyes kapcsolat (Szabó, Pászthy, és Túry, 2006) megoldatlan maradt, melynek oka alul- vagy túlstimulálás. Ez az elakadás a serdülókori genitális szakaszban újraéled, incesztuózus feszültségként.

Egy másik elmélet Dare és Crowther (1995) elgondolása, miszerint az anorexia nervosa orális fixáción alapul, anális karakterjegyekkel kiegészülve. Az étel, az ételkészítés, valamint az étkezésekre való figyelmi és konnatív beszűkülés az orális időszak központi szerepét erősíti. A kétszemélyes kapcsolatokat középpontba állító szakirodalmi áttekintések az orális időszak megoldatlanságát, az anyagyermek táplálás elégtelenségét hangsúlyozza (Szabó, Pászthy, és Túry, 2006). Az anális libidinózus késztetések tipikus vonásokat váltanak ki, úgymint a takarékosság, a perfekcionista viszonyulás, a rigiditás, a dacreakciók, valamint a hashajtó készítmények kóros használata. A genitális szakasz központi szerepének képviselői az anorexiában a péniszirigységet patogenetikai tényezőnek tekintik. A nőies formák, a másodlagos nemi jellegek elutasítása analóg a nőiség megélésének el nem fogadásával, hiszen a maszkulin vonások közelebb vezetnek az ideális énhez. A kóros testsúlycsökkenés ugyanakkor az apához füződő incesztfeszültség feloldására irányul, ami az - már említett - ödipális időszak jelentőségét hangsúlyozza. A kibontakozó nőiesség elhárításával a tudattalanul erotizált apa-lánya kapcsolat aszexualizálttá tehetô, így a korábbi biztonságos egyensúly visszaállítható (Túry és Szabó, 2000). 
Más szakemberek konkrét traumát feltételeznek, szexuális abúzust sejtenek a háttérben, ami megköveteli, hogy az érzés és az emlék disszociálódjon. A trauma szimbolikus megjelenítése az anorexiás tünet (Gáti, Túry, és Wildmann, 2001; Lane, 2002).

A tárgykapcsolat elmélet fokozatosan kezdte átvenni a korai analitikus elméletek szerepét, és a figyelem az intrapszichés konfliktusok helyett az anya-gyermek kapcsolatra, a hiányteóriára tevődött át. Az elmélet szerint a szelf- és tárgyreprezentációk sérülésiről, azok szimbolikus kifejeződéséről szólnak az evészavaros tünetek. Az alapkapcsolatokban gyökereznek a feltételezett hiányok, melyek a betegségben manifesztálódnak.

Az „elég jó” korai gondoskodás Winnicott (1999, 2004) értelmezésében az egészséges, érett szelfszerveződés alapvető kritériuma. Az anyával való szimbiózisból való kilépésben az anya szerepe az optimális frusztráció megteremtése. Ez elvezet a szeparációra való képesség kibontakozásáig, aminek alapja a tárgyállandóság. A mahleri szeparációindividuáció szakasza, az anyai funkciók és struktúrák belsôvé tétele elengedhetetlen ebben a folyamatban.

Az evészavarban szenvedőknél az alapvető szelftárgyfunkciók kialakulása, az ennek feltételeként számon tartott anya-gyermek kapcsolat sérült. Ezáltal a beteg nem képes az önmegnyugtatásra, zavart szenved a vitalizálás, az önmagunk kohéziójának, biztonságának átélése, a feszültségszabályozásra való képesség. Az anorexiás személynél az étel elutasítása az anyától való differenciálódásra való képesség sérülésére utal, így a test a „szeparációs-individuációs csaták színterévé" válik (Goodsitt, 1997).

$\mathrm{Az}$ érzelemszabályozás elégtelensége szintén az evészavaros páciensekre jellemző jelenség. Az emóciók megélése, verbalizálása, kontrollálása részlegesen vagy teljesen hiányos, emellett nehézséget okoz számukra a saját fizikai jóllétükrôl való gondoskodás is. Környezetükkel dependens viszonyt ápolnak, szüleikre, terapeutájukra támaszkodnak.

Boris (1984) az integrálhatatlan orális vágyakat tekinti központi faktornak, amiben Melanie Klein elmélete inspirálta. Az anorexia nervosát azonosí- totta azzal az alapvető problémával, hogy az érintett a számára jó dolgokat elfogadja, és ennek hátterében a kielégíthetetlen birtoklási vágyat feltételezte. Így szeretetet kapva a személy nem szembesül azzal, hogy csak részben kaphatja meg azt, így egyfajta védekezési stratégiát alkalmaz a csalódással szemben.

Közös nevezője a szelfpszichológiai elméleteknek, hogy az anya-gyermek kapcsolatban egy vitális terület, a tükrözési funkció zavart szenved. Az anya nem képes gyermekére hangolódni, saját belső állapota köti le figyelmét, energiáit. Ezáltal nem képes konténerfunkciót betölteni gyermeke vágyait, érzelmeit, nárcisztikus igényeit illetően, ezáltal a viszszatükrözés is hiányzik. Az anorexiás betegek testélményei a szülők affektív ráhangolódásának elmaradása miatt nem integráltak (Ewell, Smith, Karmel, és Hart, 1996).

A Kohut által említett empátia hiánya miatt nincs lehetősége a gyermeknek, hogy megtapasztalja saját grandiozitását, ezáltal a grandiózus szelf sérülése következik be. Az anya részéről a háttérben saját éretlensége, talán korai traumatizáló élménye, de akár pszichiátriai betegsége is állhat. Az ismétlődő empátiás hibák miatt a gyermek is hibásan alkalmazkodik szüleihez, és nem tapasztalja meg a kielégítő korai gondoskodást. Ennek következtében nem képes önmagát mint koherens, egységes szelf megtapasztalni; érzelmi és mentális állapotait azonosítani, kontrollálni nem tudja. Az érzelmi túlstimulálás eredményeként az anorexiás beteg szelfje fragmentálódik (Skarderud, 1999). Ezáltal sosem képes saját grandiózus fantáziáinak, szelfjének megfelelni.

Erős bűntudat átélése jellemzi az evészavarban szenvedőket, önmagukat hibáztatják szüleik diszkomfortjáért, illetve az ebben gyökerező érzelmi elhanyagolásért. Minden igyekezetükkel azon vannak, hogy alkalmazkodjanak a szülő gesztusaihoz, így saját érzéseiket elhanyagolják, nem veszik figyelembe, melynek hozadéka a "hamis szelf” (Winnicott, 1999, 2004). Ebből a kapcsolatból a serdülőkori individualizáció folyamatát fenyegetőként azonosítják. Önmagukat csupán másokkal való kapcsolatukon keresztül képesek definiálni. A 
maximális alkalmazkodás állapotában „mintagyerekként" funkcionálnak, amit az anorexiás megbetegedés megtör.

$\mathrm{Az}$ anorexiások jellegzetessége a kontrollhoz való kétségbeesett ragaszkodás, melyet az emóciók, a belső élmény kontrollálhatatlansága ösztönöz. A belső drive-ok - mint például az éhség - fölötti kontroll birtoklása a nárcisztikus megerősítés hiányából fakadó alacsony önértékelést átfordítja, a betegség pedig a vágyak kifejezését segíti, a tünetek fixálódásához vezet.

A felsorolt elméletek demonstrálják, hogy a terápiás munkában mennyi értelmezés lehetséges a patogenetikai tényezőket tekintve. Mindent egybevetve azonban összegezhető, hogy a terapeuta egy reparatív kapcsolat kialakításán keresztül a korai hiányok kijavítását, ezáltal a hiányzó képességek kifejlődését szolgálhatja. A hosszú távú terápiás munkában a terápiás kapcsolat a meghatározó, az interpretáció inkább másodlagos. A megélt biztonságban a kliens megismerheti önmagát, új felfedezéseket tehet belső élményvilágában.

A terápiás modellek egyike a „kétfázisú modell” (Garner, Garfinkel, és Irvine, 1986). Az első lépés a táplálkozás helyreállitása, az optimális testsúly elérése, melyhez kognitív, viselkedésterápiás és edukatív tényezőket, módszereket alkalmaznak. Kardinális szabály, hogy csupán az életveszélyes szomatikus állapot stabilizálása után indulhat a pszichoterápiás munka, a testi tünetek felól a pszichés és családi tényezôk felé haladunk.

Dévald (1993) szerint a terápiában két szint elkülönítése szükséges: a diádikus kapcsolatból származó preödipális elakadások, valamint az ödipális szakaszból eredő triádikus konfliktusok megoldatlansága. Terápiás elméletét ő is „kétfázisú modellnek” nevezte el. A terápia első szakaszában a terapeuta konténerfunkciót tölt be, és tartalmazza betege ambivalenciáját, a vonzás-taszítás viszonyulásában. Áttételi és viszontáttételi érzések váltakoznak, amik az újraközeledés elérésének nehézségeit fejezik ki. A terapeuta feladata a pszichológiai távolság kézben tartása, érzékeny módon való szabályozása, a terápiás keretek tartása. Az érzelmek átélhetőségének és expressziójának megengedése, facilitálása, a modellnyújtás és a realitás megtartása, az önbizalom erősítése a pozitív visszajelzéseken keresztül, illetve a testi kommunikáció verbalizálásba fordítása. Ezen tényezôk megvalósulása elvezethet a hatékony kliens-terapeuta viszony kialakulásához.

A terápia indulásában oppozíciós magatartás, ellenállás, ambivalencia tapasztalható, aminek feloldása, feldolgozása fontos feladat. A terapeuta frusztrációját enyhítheti az a tudás, mely szerint a terápiás segítségnyújtással szembeni elutasítás a külső kontrolltól, a kontrollálhatatlanság érzésétől való megrettenés, a testi változások legminimálisabb szintjétól való félelem. Amennyiben a páciens nyitott az első néhány alkalom „terápiás prológusán" részt venni, a kapcsolat szempontjából előrelépéseket tehetünk.

\section{Kognitivittanuláselméleti megközelités}

A mai modern, multidimenzionális szemlélet szerint az evészavarban szenvedő beteg torzult, diszfunkcionális kognícióinak megismerése alapvetó a kezelésben. A kognitív folyamatok viselkedést meghatározó szerepe általánosan elfogadott, ezért a kognitív restrukturálás, valamint a maladaptív sémák felismerése és módosítása elengedhetetlen az evészavarok, azon belül az anorexia nervosa esetében is. Az evészavaros kliensek esetében az étel elutasítása, valamint a testélménnyel összefüggő kognitív disztorziók, úgymint többek között a tökéletességre törekvés, a dichotóm gondolkodás, a szelektív absztrakció. Személyiségbeli tényezőkre is kiterjed a szemlélet, hiszen a szociálisan kevésbé hatékony viselkedésért felelőssé tehető kognitív zavarok a legtöbb esetben azonosításra kerülnek. Ezek közé tartozik a nem megfelelő megküzdési stratégia, az önértékelési zavarok, a stressz csökkentésére irányuló kompenzációs törekvések (Lukács, 2008).

Az elsődleges magyarázatok szerint viselkedéslélektani perspektívából az anorexia nervosa tanult viselkedés, fenntartásában pozitív és negatív megerősítők múködnek. Az irányzaton belül egy másik elmélet elkerülő viselkedésként értelmezi a betegséget, tehát az éhezés az evéssel és a hízással összefüggésbe hozható szorongást enyhíti. Azonban 
visszautalhatunk a tanult elemekre, mivel az éhezés mint tanult válasz örömöt vált ki a személyben. Az éhezéstôl való függőség állandósulhat, amit élettani megfigyelések is igazolnak. Összességében véve az anorexia nervosa egy komplex instrumentális kondicionálás terméke (Túry és Szumska, 2010).

Slade (1982) elmélete szerint a serdülőkori konfliktusok a családból erednek, és további interperszonális nehézségekkel társulnak. A familiáris környezetben a függetlenedés és autonómia, a társas szorongás, valamint a pszichésen megterhelő események okoznak problémát. Általános elégedetlenségérzés követi a helyzetet, ami a perfekcionizmussal kiegészülve arra készteti a gyermeket, hogy élete valamelyik területe fölött teljes kontrollra tegyen szert. A legjobb lehetőség erre az önkontroll és a saját ellenőrzésének birtoklása, hiszen ebben mások viselkedésétól függetlenül lehet jelen. Ennek táptalaján bizonyos precipitáló tényezók, mint például a kortársak kritikája, a testsúly csökkentésére történő kísérleteket inspirálhatnak. Amennyiben sikerélmény és kielégültségérzés társul, pozitív megerősítés történik. Negatív megerősítés a hízással szembeni averzió és a stresszhelyzetek elkerülése irányában alakulhat ki. A folyamat eredményeként fokozódik a diétázási magatartás, és egy körforgásként újraaktiválódnak a kezdeti lépések.

Bruch (1966) kognitív-behaviorista modellje az anorexia nervosában kognitív torzulásokat feltételez. Az érintett betegek elakadtak a fogalom előtti vagy konkrét gondolkodás szintjén, és az egocentrizmus, valamint a mágikus effektivitás, az omnipotencia élménye rögzült. A testkép zavara perceptuálisan és konceptuálisan egyaránt értelmezhetô, és mind a testre vonatkozó percepciós készség, mind az ételek méretének és mennyiségének becslése túlzó. A testsúly-alak-evés hármasa torzult, mely a tüneti kép előterében álló pszichopatológiai elváltozásokat okozza.

Garner és Bemis (1985) szintén kognitívviselkedéslélektani modellt fogalmazott meg az anorexia nervosa magyarázatára. Szintén a diétázás pozitív megerősítésével indul gondolatmenetük: önmagát a súlykontroll megtartása motiválja, a társadalom részéről pedig a karcsúságideálnak való megfelelés előnyös. A betegség felszínre kerülésével a társas környezet aggodalma további megerősítőként hat. A testsúly egyre fokozottabb csökkenésével a külső megerősitők szerepe is csökken, és az anorexiás hiedelmek és viselkedésformák önállósodni kezdenek. A szociális izoláció felerősödésével a beteg egyre védtelenebb saját diszfunkcionális gondolataival szemben. Az éhezés emocionális és kognitív funkciókra gyakorolt hatása tovább mélyíti a társas elidegenedést, amihez az anxio-depressziv tünetek is hozzájárulnak.

Kognitív tényezőkön is alapul az az elmélet, mely szerint a testalakra és a -súlyra vonatkozó diszfunkcionális gondolatok szorongáskeltőek, és a motiváció iránya a szorongás redukciója, a testsúly csökkentésére tett fanatikus kísérletek. Az elméletben az említett dinamikán kívül szerepet kap a testképzavar, az elhízás és a test méretei miatti aggodalom (Williamson, Davis, Duchmann, McKenzie, és Watkins, 1990).

Fairburn (Fairburn, Shafran, és Cooper, 1999) a korábbi elméletekből merítette saját elképzeléseit, azonban ő is az evés fölötti kontroll fokozott szükségletét állította az anorexia nervosa pszichopatológiájának központjába. Újszerű, de vizsgálatokkal alátámasztott állítása, hogy a súly és az alak miatti aggodalom nem alapvető jegyei a betegségnek. Az anorexiáról alkotott modellje értelmében az evés fölötti kontroll megélése hozzájárul az általános önkontroll-érzés erősödéséhez. A prefekcioniz-mus társuló személyiségjegy, azonban maladap-tív formát öltve extrém szigorú szabályok közötti diétát jelent. Az érintett személy érdeklődése beszűkül, ezáltal lehetővé válik más területek problémáinak a negálása. Az önértékelés tehát egyedül a sikeres önkontroll függvénye marad, így megvédi a beteget a más területeken tapasztalható kudarcok elszenvedésétôl.

Az evészavarok későbbi, transzdiagnosztikus elmélete négy elemre alapoz: alacsony önértékelés, hangulati szenzitivitás, klinikailag jelentős intenzitású perfekcionizmus, személyközi nehézségek (Fairburn és mtsai., 1999). A testsúly és testalak túlzott hangsúlyozása szerepet kap a modellben. A korábbi elméletektôl eltérően ez az elméleti elgon- 
dolás valamennyi evészavar magyarázatára akar jutni, a klinikai szintet el nem érő zavarok és a máshová nem sorolható evési zavarokra vonatkozóan is. A négy elem mind hajlamosító, mind fenntartó tényezőként is funkcionálhat, és az egyéni eltérések igazolásában különböző mértékük informatív lehet.

A korábbi elméletek revideált változatai és az új elméletek minimálisan hat új előfeltevést igazolnak (Cooper, 2005) , melyek közül az anorxia nervosára vonatkozók a következők: az önkontroll jelentősége kiemelkedő; a szigorú diéta erôsíti a kontrollérzést; az éhezés fokozza az extrém diétát; a perfekcionizmus kulcsfontosságú, valamint az interperszonális problémák meghatározó szerepet játszanak.

A második generációs kognitív elméletek a korábbi vizsgálati eredményeket figyelembe véve még szélesebb körben igyekeznek törvényszerúségeket feltárni az evészavarokra vonatkozóan. Továbbra is előtérbe helyezik a kogníciók-érzelmek-viselkedés kapcsolatát (Cooper, 2005). Az anorexia nervosa szempontjából a bulimiától való eltérést vizsgálták (Waller, Kennerley, és Ohanian, 2004), és megállapították, hogy előbbieknél a distresszt kiváltó gondolatok és érzések elhárítása az étel elutasításában ölt testet. Elsődleges elkerülésnek nevezhetjük a jelenséget, hiszen a viselkedés már a gondolatok, érzések előtt fellép. Tehát preventív mechanizmusról beszélhetünk, míg a bulimia esetében másodlagos elkerülés történik, hiszen a falásrohamok „kezelik" a már fennálló diszkomfortérzetet.

Szintén újabb elmélet Wolff és Serpell (1998) eredménye, ami a szelfséma szerepét állapította meg az emocionális szabályozásban, illetve a specifikus kogníciókra helyezi a hangsúlyt, mint például a betegség szubjektív megélése, értékelése. Kétféle kogníció-típust azonosított: „proanorexia”, ami a személyiség összetartójaként értékeli a betegséget, valamint ,antianorexia”, ami a bűnbak szerepével látja el a kórképet. További újszerűsége a szerzőpárosnak, hogy mind a negatív, mind a pozitív automatikus gondolatoknak jelentőséget tulajdonít a zavar fennmaradásában.

A második generációs elméletek azonban még mindig nem teljességgel ragadják meg a patológiás mechanizmusokat, ezért további vizsgálatok szükségesek, elsősorban az önfenntartó folyamatok, a típusos kogníciók, valamint a kognitív hiedelmek és előfeltevések tekintetében (Lukács, 2008).

\section{Pszichoterápiás hatékonyságvizsgálatok}

Az anorexia nervosát magyarázó megközelítések alapján (vö.: 1. ábra) a terápia irányulhat az inputokra, az információfeldolgozó folyamatra, a viselkedésre, illetve a társas környezet bevonását is feltételezheti - több vizsgálat által nyert igazolást például, hogy az evészavarok terápiájában a családterápia jogosan foglal el központi szerepet, hiszen a betegség kialakulásában és fenntartásában a családi rendszer szerepe jelentős (Túry, Wildmann, László, és Joó, 1999).

A kognitív viselkedésterápia az evészavarok kezelésének egyik leghatékonyabb terápiás módszere (Túry és Szabó, 2000). Az anorexia nervosában történő alkalmazása kapcsán a vizsgálatok többnyire kisebb mintán történtek. Ambuláns keretek között zajló csoportos kognitív viselkedésterápiát követôen, majd egy későbbi időpontban kontrollvizsgálat alkalmával a patológiás tünetek számának csökkenését sikerült igazolni (Fernandez-Aranda és mtsai., 1998). Szintén ambuláns ellátásban háromféle csoportterápia került összevetésre: hagyományos viselkedésterápia, eklektív terápia és kognitív behaviorterápia. A súlygyarapodás és a szociális készségek javulása tekintetében a 6 és 12 hónappal későbbi utánkövetés nem jelzett szignifikáns különbséget a terápiás csoportok között (Channon, de Silva, Hemsley, és Perkins, 1989). A kognitív viselkedésterápia és a viselkedésorientált családterápia szintén nem mutat hatékonyságát tekintve eltérést az anorexia nervosa kezelésében (Ball, 1999). Ezek a korai vizsgálatok még nem tudták igazolni a kognitív viselkedésterápia kiemelt hatékonyságát az anorexia esetében, azonban a kezelésre irányuló valóban eredményes módszerek kidolgozása ekkor még nem ért véget (Wilson, 1999).

A randomizált kontrollvizsgálatok a serdülőkori anorexia nervosa pszichológiai terápiáját illetően tovább folytatódtak. Eisler és munkatársai (Eisler, Dare és Hodes, 2000) nem találtak szignifikáns kü- 
lönbséget az együttes és az elkülönült ülésekkel zajló családszemléletú terápiák között. Azonban azokban a családokban, ahol a kifejezésre jutó anyai kritikusság magasabb szintú volt, a szeparált terápiás elrendezés hatékonyabb volt.

A kognitív viselkedésterápiák összehasonlítva a viselkedéses rendszerekre épülő családterápiákkal nem hoztak eltérő kimeneti eredményt (Ball és Mitchell, 2004). A multidiszciplináris osztályos bentfekvéssel alkalmazott pszichiátriai terápiák, az ambuláns specifikus evészavar-kezelések (kognitív viselkedésterápia, szülőkonzultáció, diétával kapcsolatos megbeszélés, a multimodális feedback), valamint a közösségi mentálhigiénés ellátásban alkalmazott hagyományos terápiák nem mutatnak szignifikáns eredménybeli eltérést (Gowers, Clark és Roberts, 2007). Az ambuláns kezelésról azonban elmondható, hogy sokkal költséghatékonyabb, és a kliens részéről nagyobb az elköteleződés. A specifikus kezelések a szülők részéről magasabb elégedettségi szintet jeleztek.

Lock és munkatársai (Lock, Agras, Bryson, 2005) a 20 és a 10 üléses rendszerszemléletú terápiát vizsgálták meg, és a kezelés rövid vagy hosszú távú lefolyását nem találták befolyásoló erejűnek. Azonban későbbi eredmények bebizonyították, hogy amennyiben az evészavar súlyos obszesszívkompluzív tünetekkel szövődik, és a család sem intakt, a hosszú távú kezelés célravezetôbb.

A rendszerszemléletú terápiák illetve ugyanezen terápiák a szülők közötti konzultációval kiegészülve szintén a hatékonyságvizsgálatok górcsője alá kerültek. Rhodes és munkatársai (Rhodes, Baillee, és Brown, 2008) szerint a kétféle kezelés célkitűzéseinek megvalósulása között nem mutatkozott különbség, azonban kvalitatív elemzések feltételezik, hogy a szülők megerôsítést élnek meg, és kevésbé érzik magukat egyedül hagyva a feladattal, ha szülószülő konzultációra is van lehetőség.

Lock és munkatársainak egy későbbi vizsgálata (Lock, Le Grange, és Agras, 2010) a rendszerszemléletû́ terápiát a serdülő-fókuszú terápiával hasonlította össze. A kezelés végén elmondható, hogy a rendszerszemléletú terápia szignifikánsan nagyobb súlynövekedéshez vezetett, és a globális evészavar- mutató csökkent értéket mutatott. A remissziók tekintetében nem került feltárásra eltérés a két módszer között, habár a rendszerorientált terápia az utánkövetés során (6 és 12 hónap) nagyobb arányban jelzett remissziót (49\% és 23\%).

A hagyományos terápia és ugyanezen terápia kiegészülve a kapcsolatszemléletú családterápiával utóbbi erôsségét igazolja (17,2\% szemben a 40 \%kal) (Godart, Berrthoz, és Curt, 2012).

A fent bemutatott pszichológiai hatékonyságvizsgálatok összegzéseként elmondható, hogy az ambuláns ellátás a serdülőkori anorexia nervosa első számú ellátási formája. A legtöbb gyermek és serdülő számára az anorexia nervosa kezelésében a rendszerszemléletú terápia vagy egyéb módosított családterápiás megközelítés a leghatékonyabb. Az egyéni terápia az idősebb serdülő korosztály számára jelent a betegségben előnyös alternatívát, abban az esetben, amikor a családterápia nem alkalmas kezelési mód. Az egyéni terápiák közül a serdülőfókuszú terápiák valamint a kognitív viselkedésterápiák alternatívaként szolgálnak. A hagyományos terápia nem javasolt az ado-leszcens anorexia nervosa kezelésében. Kiegészítésként fel kell hívni arra a figyelmet, hogy az anxiolitikumokat, antidepresszánsokat vagy egyéb farmakonokat csak különös óvatossággal szabad alkalmazni (Hay és mtsai., 2014).

\section{Összefoglalás}

Jelen áttekintés összegzéseként hangsúlyozandó, hogy a különleges bánásmódot igénylő személyekkel kapcsolatban álló különböző szakemberek együttmúködése nélkülözhetetlen. Ez a megállapítás az evészavarok, különös tekintettel az anorexia nervosa esetében is helytálló. A kórkép hosszú távú pszichés, szomatikus, szociális szövődményei további nehézségeket idézhetnek elő, ami újabb szakemberek bevonását, illetve egyéb kezelési módok bevezetését is szükségessé tehetik. A korai diagnosztika és az érintett személy számára leghatékonyabb ellátás kiválasztása megállithatja a problémák halmozódását, és egy minőségibb életforma megalapozásában nyújthat segítséget. 


\section{IRODALOM}

Bailey, C. A. (1991). A family structure and eating disorders: The Family Environment Scale and bulimic-like symptoms. Youth \& Society, 23, 251 272. doi: 10.1177/0044118X91023002005

Ball, J. (1999). A controlled evaluation of psychological treatments for anorexia nervosa. Unpublished doctoral dissertation, University of New South Wales, Australia. In: Wilson, G. T. (1999). Cognitive behaviour therapy for eating disorders: progress and problems. Behav. Res. Therapy, 37, 79-95.

Ball, J. \& Mitchell, P. (2004). A randomized controlled study of cognitive behavior therapy and behavioral family therapy for anorexia nervosa patients. Brunner-Mazel Eating Disorders Monograph Series 12, 303-14. doi: 10.1080/10640260490521389

Becker, H. (1980). Die Vater-Tochter-Beziehung in der Familiendynamik bei Anorexia nervosaPatietinnen. Nervenarzt, 51, 568-572.

BNO-10 Zsebkönyv. DSM-IV-TR meghatározásokkal. Animula. Budapest, 2004.

Boris, H. N. (1984). On the treatment of anorexia nervosa. Int. J. Psychoanalysis, 65, 435-442.

Bruch, H. (1966). Anorexia Nervosa and its differential diagnosis. J. Nerv. Ment. Dis. ,141, 555-566. doi: 10.1097/00005053-19651100000008

Bulik, C. M., Marcus, M. D., \& Zerwas, S. (2012). The changing "weightscape" of bulimia nervosa. American Journal of Psychiatry, 169, 10311036.

Casper, R.C. \& Troiani, M. (2001). Family functioning in anorexia nervosa differs by subtype. International Journal of Eating Disorders, 30, 338-342. doi: 10.1002/eat.1093

Channon, S., De Silva, P., Hemsley, D. \& Perkins, R. (1989). A controlled trial of cognitivebehavioural and behavioural treatment of anorexia nervosa. Behav. Res. Therapy, 27, 529-535. doi: 10.1016/0005-7967(89)90087-9

Condit, V. K. (1990). Anorexia nervosa: Levels and causation. Human Nature, 1, 391-413.

doi: 10.1007/BF02734052
Cooper, M. J. (2005). Cognitive theory in anorexia nervosa and bulimia nervosa: progress, development and future directions. Clinical Psychology Review, 25, 511-531. doi: 10.1016/j.cpr.2005. 01.003

Dare, C. \& Crowther, C. (1995). Psychodynamic models of eating disorders. In: Szmukler, G., Dare, C., Treasure, J. (szerk.) Handbook of eating disorders. John Wiley \& Sons, Chichester, 125139.

Dévald P. (1993). Öndestruktivitás az evészavarokban. Pszichoanalitikus Gyermek- és Serdülőterápiás Intézet, Budapest.

DSM-5 referencia-kézikënyv a DSM-5 diagnosz̨tikai kritériumaihoz: Oriold és Társai. Budapest, 2014.

Eating Disorders Toolkit - A Practice-Based Guide to the Inpatient Management of Adolescents with Eating Disorders, with Special Reference to Regional and Rural Areas (2008). Letöltés: 2019.04.05. Web: http://cedd.org.au/ wordpress/wp-content/uploads/2013/09/MHKids-Eating-Disorders-Toolkit-A-PracticeBased-Guide-to-the-Inpatient-Management-ofAdolescents-with-Eating-Disorders.pdf

Eisler, I., Dare, C., \& Hodes, M. (2000) Family therapy for adolescent anorexia nervosa: The results of a controlled comparison of two family interventions. Journal of Child Psychology and Psychiatry, 41: 727-736. doi: 10.1111/1469-7610.00660

Epstein, N. B. \& Bishop, D.S. (1987). Problémacentrikus rendszerelméleti családterápia. Magyar Pszichiátriai Társaság Családterápiás Munkacsoport, 8. füzet.

Ewell, F., Smith, S., Karmel, M. P., \& Hart, D. (1996). The sense of self and its development: a framework for understanding eating disorders. In: Smolak, L., Levine, M. P., Striegel-Moore, R. (szerk.) The developmental psychopathology of eating disorders. Lawrence Erlbaum Associates, New Jersey, 107-133.

Fairburn, C. G., Shafran, R., \& Cooper, Z. (1999). A cognitive behavioural theory of anorexia nervosa. Behav. Res. Therapy 37, 1-13. doi: 10.1016/S0005-7967(98)00102-8 
Favaro, A., Ferrara, S., \& Santonastaso, P. (2003). The spectrum of eating disorders in young women: A prevalence study in a general population sample. Psychosomatic Medicine 65, 701-708. doi: 10.1097/01.PSY.0000073871. 67679.D8

Fernandez-Aranda, F., Bel, M., Jimenez, S., Vinuales, M., Turon, J., \& Vallejo, J. (1998). Outpatient group therapy for anorexia nervosa: a preliminary study. Eating \& Weight Disorders 3, 1-6. doi: 10.1007/BF03339981

Ferreira, C., Gouveia, J. P., \& Duarte, C. (2013). Drive for thinness as a women's strategy to avoid inferiority. International Journal of Psychology \& Psychological Therapy, 13, 15-29.

Fisher, M. (2006). Treatment of eating diorders in children, adolescents and young adults. Pediatr. Rev., 27, 34-45.

Friedman, M. A., Wilfey, D. E., Welch, R. R., \& Kunce, J. T. (1997). Self directed hostility and family functioning in normal-weight bulimics and overweight binge eaters. Addictive Behaviors, 22, 367-375. doi: 10.1016/S0306-4603(97)80001-9

Garner, D. M., \& Bemis, K. M. (1985). Cognitive therapy for anorexia nervosa. In: Garner, D. M., Garfinkel, P. E. (szerk.). Handbook of psychotherapy for anorexia nervosa and bulimia. Guilford, New York, 107-146.

Garner, D. M., Garfinkel, P. E., \& Irvine, M. J. (1986). Integration and sequencing of treatment approaches for eating disorders. Psychother. Psychosom., 46, 67-75. doi: 10.1159/000287963

Gáti Á., Túry F., \& Wildmann M. (2001). A bántalmazás multimodális terápiás megközelítése anorexia nervosában. Pychiatria Hungarica, 16, 669-676.

Godart, N., Berrthoz, S., \& Curt, F. (2012) A randomized controlled trial of adjunctive family therapy and treatment as usual following inpatient treatment for anorexia nervosa adolescents.

PLoS ONE [Electronic Resource] 7, 1-9. doi: 10.1371/journal.pone.0028249
Goodsitt, A. (1997). Eating disorders: a selfpsychological perspective. In: Garner, D. M., Garfinkel, P. E. (szerk.): Handbook of treatment for eating disorders. The Guilford Press, New York, 205-226.

Gowers, S. G., Clark, A., \& Roberts, C. (2007). Clinical effectiveness of treatments for anorexia nervosa in adolescents: Randomised controlled trial. British Journal of Psychiatry 191, 427-435. doi: 10.1192/bjp.bp.107.036764

Guisinger, S. (2003). Adapted to flee famine: Adding an evolutionary perspective on anorexia nervosa. Psychological Review, 110, 745-761. doi: 10.1037/0033-295X.110.4.745

Harsányi I. (1965). Iskolások családrajza mint a családi relációk és az önértékelés feltárásának eszközze. MTA Pszichológiai Bizottsága, Budapest.

Hay, P., Chinn, D., Forbes, D., Madden, S., Newton, R., Sugenor, L., Touyz, S., \& Ward, W. (2014). Royal Australian and New Zealand College of Psychiatrists clinical practice guidelines for the treatment of eating disorders. Australian \& New Zealand Journal of Psychiatry, 48(11), 1-62. doi: 10.1177/0004867414555814

Hudson, J. I., Hiripi, E., \& Pope, H. G. (2007). The prevalence and correlates of eating disorders in the National Comorbidity Survey Replication. Biological Psychiatry, 61, 348-358. doi: 10.1016/j.biopsych.2006.03.040

Jánosi A. \& Túry F. (2014). Étel és test a civilizáció (torz) tükrében. Az evészavarok evolúciós elméletei. In Gyuris P, Meskó N., \& Tisljár R. (Eds.), Az evolúció ármyoldala. Akadémiai Kiadó, Budapest, 162-180.

Jeammet, P., Gorge, A., Zweifel, R., \& Flavigny, H. (1973). Le milieu familial des anorexiques mentaux. Incidences sur le traitement. Ann. Med. Interne, 124, 247-252.

Jozefik, B., Iniewicz, G. Namyslowska, I., \& Ulsaniska, R. (2002). Assessment of family relations by the patients suffering from anorexia nervosa - Part I, II. Psychiatria Polska, 36, 51-81.

Juda, M. N., Campbell, L., \& Crawford, C. B. (2004). Dieting symptomatology in women and perceptions of social support: An evolutionary 
approach. Evolution and Human Behavior, 25, 200-208.

Karwautz, A., Haidvogl, M., Wagner, G., Nobis, G., Wober-Bingol, C., \& Friedrich, M. H. (2002). Subjective family image ina anorexia nervosa and bulimianervosa in adolescence: a controlled study. Zeitschrift für Kinder- und Jugendpsychiatrie und Psychoterapie, 30, 252-259.

Karwautz, A., Haidvogl, M., Wagner, G., HafferGattermayr, A., Wöber-Bingöl, C., \& Friedrich, M. H. (2003). Perceptions of family relationships in adolescents with anorexia nervosa and their unaffected sister. European Child \& Adolescent Psycbiatry, 12, 128-135. doi: 10.1007/s00787-003-0319-1

Kaye, W. H., Bulik, C. M., \& Thornton, L. (2004). Comorbidity of anxiety disorders with anorexia and bulimia nervosa. Am. J. Psycbiatry, 161, 2215-2221. doi: 10.1176/appi.ajp.161.12.2215

Kee, P., Heatherton, T., Harnden, J., \& Hornig, C. (1997). Mothers, fathers and daughters: Dieting and disordered eating. Eating Disorders, 5, 216228.

Lane, R. C. (2002). Anorexia, masochism, selfmutilation, and autoerotism: the spider mother. Psychoanalytic Review, 89, 101-123.

Lask, B. \& Bryant-Waugh, R. (2007). Eating disorders in childhood and adolescence. Routledge, New York.

Lock, J., Agras, W. S., \& Bryson, S. (2005). A comparison of short- and long-term family therapy for adolescent anorexia nervosa. Journal of the American Academy of Child \& Adolescent Psychiatry 44, 632-639. doi: 10.1097/01.chi.0000161647.82775.0a

Lock, J., Le Grange, D., \& Agras, W. S. (2010). Randomized clinical trial comparing familybased treatment with adolescent-focused individual therapy for adolescents with anorexia nervosa. Archives of General Psychiatry, 67, 1025-1032.

doi: 10.1001 /archgenpsychiatry.2010.128

Lukács L. (2008). A kognitív információfeldolgozás sajátosságainak újabb eredményei az evészavarok terén. In: Túry F. és Pászthy B. (szerk.).
Evészavarok éstestképzavarok. Pro Die, Budapest, 211-222.

Madden, S., Morris, A., \& Zurynski, Y.A. (2009). Burden of eating disorders in 5-13-year-old children in Australia. The Medical Journal of Australia, 190, 410-414.

Mező F. (2011). Tanulás: diagnosztikea és fejlesztés az IPOO-modell alapján. K+F Stúdió Kft., Debrecen.

Mező, F. \& Mező, K. (2005). Tanulási stratégiák fejlesztése az IPOO-modell alapján. Kocka Kör Tehetséggondozó Kulturális Egyesület, Debrecen.

Minuchin, S. (1974). Families and family therapy. Harvard University Press, Cambridge, Massachusettes.

Nicholls, D., Chater, R., \& Lask, B. (2000). Children into DSM don't go: a comparison of classification systems for eating disorders in childhood and early adolescence. International Journal of Eating Disorders, 28, 317-324.

Ogden, J. \& Steward, J. (2000). The role of the mother-daughter relationship in explaining weight concern. International Journal of Eating Disorders, 28, 78-83. doi: 10.1002/(SICI)1098108X(200007)28:1\%3C78::AID-EAT9\%3E3.0. $\mathrm{CO} ; 2-\mathrm{N}$

Okon, D., Greene, A. L., \& Smith, J. E. (2003). Family interactions predict intraindividual symptom variation for adolescents with bulimia. International Journal of Eating Disorders, 34, 450457. doi: 10.1002/eat.10215

Onnis, L. (1993). A pszichoszomatikus zavarok rendszerszemlélete. Családterápiás sorozat 3., Budapest.

Pászthy B. (2007). A gyermek- és serdülőkorban kezdődő anorexia nervosa szomatikus szövődményei. Orvosi Hetilap, 149, 405-412.

Peebles, R., Wilson, J. L., \& Lock, J.D. (2006). How do children with eating disorders differ from adolescents with eazing disorders an initial evaluation? Journal of Adolescents Health, 6 , 800-805.

Rapaport, D., Gill, M.M., \& Schafer, R. (19451946). Diagnostic psychological testing. Year Book Publishers Vol. 1., 2. , Chicago. 
Rhodes, P., Baillee, A., \& Brown, J. (2008). Can parent-to-parent consultation improve the effectiveness of the Maudsley model of familybased treatment for anorexia nervosa? A randomized control trial. Journal of Family Therapy $3096-108$ doi: 10.1111/j.1467-6427.2008.00418.x

Rikani, A. A., Choudhry, Z., Choudhry, A. M., Ikram, H., Asghar, M. W., Kajal, D.,\& Mobassarah, N. J. (2013). A critique of the literature on etiology of eating disorders. Annals of Neurosciences, 20, 157-161. doi: 10.5214/ans.0972.7531.200409

Roberts, S. C., \& Miner, E. J. (2010). The Future of an Applied Evolutionary Psychology for Human Partnerships. Review of General Psychology, 14, 318-329. doi: 10.1037/a0021253

Rorty, M., Yager, J., Rossotto, E., \& Buckwalter, G. (2000). Parental intrusiveness in adolescence recalled by women with a history of bulimia nervosa and comparison women. International Journal of Eating Disorders, 28, 202208.

doi: 10.1002/1098-108X(200009)28:2\% 3C202::AID-EAT9\%3E3.0.CO;2-G

Salmon, C., Crawford, C. B., \& Walters, S. (2008). Anorexic Behavior, Female Competition and Stress: Developing the Female Competition Stress Test. Evolutionary Psychology, 6, 96-112. doi: 10.1177/147470490800600112

Selvini-Palazzoli, M., Boscolo, L., Cecchin, G., \& Prata, G. (1974). The treatment of children through brief therapy of their parents. Family Process, 13, 429-442.

Shoebridge, P. \& Gowers, S. G. (2000). Parental high concern and adolescent-onset anorexia nervosa. A case-control study to investigate direction of causality. British Journal of Psychiatry, 176, 132-137.

Slade, P. D. (1982). Towards a functional analysis of anorexia nervosa and bulimia nervosa. Brit. J. Clin. Psychol, 21, 167-179. doi: 10.1111/j.2044-8260.1982.tb00549.x

Steinhausen, H. C. (2002). The outcome of anorexia nervosa in the 20th century. American Journal of Psychiatry, 159, 1284-1293.

doi: 10.1176/appi.ajp.159.8.1284

Surbey, M. K. (1987). Anorexia, amenorrhea, and adaptation. Ethology and Sociobiology, 8, 47-61.

Steiger, H., Bruce, K., \& Israel, M. (2003). Eating disorders. In G. Stricker, T. A., Widiger, \& B. Weiner (Eds.) Handbook of psychology, Vol. 8, Clinical psychology. John Wiley \& Sons Inc., New York, 173-194. doi: 10.1002/0471264385. wei0807

Szabó L., Pászthy B., \& Túry F. (2006). Az apák szerepe az evészavarok családdinamikájában. Pszichoterápia, 15, 406-415.

Sztanó F., Ress K. \& Pászthy B. (2007). Az evészavarok családi kockázati és protektív tényezői. Mentálhigiéné és Pszichoszomatika, 8, 49-61.

Túry F., Simon L., Wildmann M., \& Kiss K. (1994). Az anorexia hazai történetének korai forrásai. Lege Artis Medicinae, 4, 1152-1158.

Túry F., Lukács L., Rácz O., \& Horváth K. (2003). Az evés-és a testképzavarok újabb megnyilvánulásai. Lege Artis Medicinae, 13, 642-647.

Túry F. \& Pászthy B. (szerk.) (2008). Evészavarok és testképravarok. Pro Die, Budapest.Túry F. \& Szabó P. (2000). A táplálkozási magatartás zavarai: az anorexia nervosa és a bulimia nervosa. Budapest: Medicina.

Túry F. \& Szumska I. (2005). Az étkezési zavarok kognitív viselkedésterápiája. In: Mórotz $K$. és Perczel F. D. (szerk.). Kognitiv viselkedésterápia. Medicina, Budapest, 499-526.

Túry F., Wildmann M., László ZS., \& Joó M.N. (1999). Családterápiás munkánk értékelése a táplálkozási magatartás zavaraiban. Psychiatria Hungarica, 14, 694-703.

Vandereycken, W., Kog, E., \& Vanderlinden, J. (1989). The Family Approach to Eating Disorders. PMA Publishing Corp, New York, 189-225.

Voland, E., \& Voland, R. (1989). Evolutionary biology and psychiatry: The case of anorexia nervosa. Ethology and Sociobiology, 10, 223-240. doi: 10.1016/0162-3095(89)90001-0

Waller, G., Kennerley, H., \& Ohanian, V. (2004). Schema-focused cognitive bahaviour therapy with the eating disorders. In: du Toit, P. 
(szerk.). Cognitive schemas and core beliefs in psychological problems: a scientist practitioner guide. American Psychiatric Association, Washington.

Wasser, S. K., \& Barash, D. P. (1983). Reproductive suppression among female mamals: Implications for biomedicine and sexual selection theory. Quarterly Review of Biology, 58, 513-538.

Whelan, E. \& Cooper, P. J. (2000). The association between childhood feeding problems and maternal eating disorder: a community study. Psychological Medicine, 30, 69-77. doi: 10.1017/S0033291799001543

Williamson, D. A., Davis, C. J., Duchmann, G.G., McKenzie, S. J., \& Watkins, P. C. (1990).
Assessment of eating disorders: obesity, anorexia and bulimia nervosa. Pergamon, New York.

WiIson, G. T. (1999). Cognitive behaviour therapy for eating disorders: progress and problems. Behav. Res. Therapy, 37, 79-95.

Winnicott, D. W. (1999). Játszás és valóság. Animula, Budapest.

Winnicott, D. W. (2004). A kapcsolatban bontakozó lélek. Új Mandátum Könyvkiadó, Budapest.

Wolff, G. \& Serpell, L. (1998). A cognitive model and treatment strategies for anorexia nervosa. In: Hoek, H., Treasure, J., Katzman, M. (szerk.). Neurobiology in the treatment of eating disorders. Wiley, Chichester. 